\title{
Accumulation Characteristics of Some Elements in the Moss Polytrichum commune (Bryophytes) Based on XRF Spectrometry
}

\author{
Rudolf Šoltés, Eva Gregušková \\ Institute of High Mountains Biology, University of Žilina, Tatranská Javorina, Slovakia. \\ Email: rudolf.soltes@uniza.sk, eva.greguskova@uniza.sk \\ Received February $18^{\text {th }}, 2013$; revised March $21^{\text {st }}, 2013$; accepted April $19^{\text {th }}, 2013$ \\ Copyright (C 2013 Rudolf Šoltés, Eva Gregušková. This is an open access article distributed under the Creative Commons Attribution \\ License, which permits unrestricted use, distribution, and reproduction in any medium, provided the original work is properly cited.
}

\begin{abstract}
Bryophytes are broadly used as bioindicators. However, the internal distribution of accumulated elements in the moss tissue is little known. Sampling was carried out in The West Carpathians, Slovakia, in autumn 2012. Seven replicates have been used. The samples were analyzed by XRF Spectrometer Delta Classic. S, Pb, K, Ca, Cr, Mn, Fe, Cu, Rb, Sr, $\mathrm{Mo}, \mathrm{Ba}$ and $\mathrm{Zn}$ were determined. For ordination analysis we used principal component analysis, statistical graphics system STATISTICA have been used for the correlation analysis and for analysis of variance. Results show that sulphur, zinc, chromium, manganese, molybdenum, kalcium and copper are preferentially accumulated in the capsula. While lead favors gametophyte, potassium and strontium prefer accumulation in sporophyte. Iron significantly accumulates in the more-year segments, while zinc in the stems. Copper, chromium and sulphur are accumulated preferentially in The Fatra Mts.
\end{abstract}

Keywords: Bioindication; Polytrichum commune; The West Carpathians; Elemental Accumulation; XRF Spectrometry

\section{Introduction}

Mosses are suitable in the bioindication of heavy metal deposition because they are perennial without deciduous periods, they have high cation exchange capacity and the cuticle is absent $[1,2]$.

Although the method of bryoindication in foreign countries has been broadly used, from Slovakia, distinctively from the Tatra Mts are only moderate data present. Šoltés [3] evaluated results of chemical analysis of 267 samples of 26 bryophyte species collected on the territory of the High Tatra Mts, including Polytrichum commune Hedw. The peat moss Sphagnum girgensohnii Russow used Šoltés [4] for bioindication of imission load of Tatra Mts with special focus to correlation between altitude and heavy metal deposition.

Polytrichum commune has been often used as bioindicator. Sidhu [5] found that fluorine accumulation in the moss Polytrichum commune was about 10 times greater than in the needles of Abies balsamea. Wenstein and Davison [6] reminded than larger fluorine accumulation in the moss Polytrichum commune might be interpreted as reflecting the much greater resistence of Polytrichum commune to fluorine. Busoic et al. [7] used Polytrichum commune for $\mathrm{Cr}, \mathrm{Pb}, \mathrm{Sr}, \mathrm{Cu}, \mathrm{Zn}, \mathrm{Co}, \mathrm{Mn}$ and $\mathrm{Fe}$ biomonitoring in Tisa river valley (Romania). Irudayaraj et al. [8] used spore germination of Polytrichum commune to assess the toxicities of heavy metals $\mathrm{Cu}, \mathrm{Cd}$ and $\mathrm{Zn}$. Markert and Wtorova [9] used samples of Polytrichum commune to evaluate environmental contamination in Forest Biosphere Reserve near Kalinin. Šoltés et al. [10] used Polytrichum commune to specify the imission influence to non-forest vegetation of the Tatra Mts. Polytrichum commune has shown as a highly sensitive indicator. Maňkovská et al. [11] collected 831 samples of six bryophyte species, including Polytrichum formosum in order to identify the areas affected by industrial imissions.

Differences in heavy metals accumulation both in gametophyte and sporophyte have been recorded by more authors. Xie and Zhang [12] noticed that gametophytes of Funaria hygrometrica accumulated significantly more heavy metals than sporophytes, while concentrations of $\mathrm{Zn}$ and $\mathrm{Mn}$ in sporophytes were always higher than con- 
centrations of other heavy metals. Similar results obtained Basile et al. [13], also using Funaria hygrometica.

Water conduction in Polytrichum commune is entirely carried out by the central strand [14]. The Polytrichum species are well adapted to winter conditions. The lamellar cells of frozen plants are desiccated, the cytosol is shrunken, the ribosomes and mitochondria are aggregated. The thylakoid system of their chloroplasts is irregularly arranged and the grana thylakoids are compressed [15].

Apart from Polytrichum commune, other Polytrichum species have been used for bioindication also. Grodzińska and Godzik [16] determined $\mathrm{Cd}, \mathrm{Pb}, \mathrm{Ni}, \mathrm{Cu}, \mathrm{Zn}$ and $\mathrm{S}$ in moss species collected in southern Spitzbergen. They found Polytrichum alpinum as a poor accumulator of heavy metals.

Even if bryophytes have been extensively used as bioindicators of environmental pollution, still little is known about the internal distribution of heavy metals in the moss tissue.

The following questions are addressed in this paper:

- How accumulated elements are distributed in the tissue of Polytrichum commune;

- How accumulated elements are correlated;

- Evaluation of the convenciency of the species Polytrichum commune for bioindication.

\section{Methods}

\subsection{Sampling}

The samples of Polytrichum commune were collected in fairly open stand with a distance of $5 \mathrm{~m}$ to the nearest tree. After the return to the laboratory, the plant samples were washed in distilled water and dried at $70^{\circ} \mathrm{C}$ for two days. After drying, the one-year segments were separated. Growth segments are easy to regonized, they are formed by annualy repeated changing patterns of leaf morfology [17]. The geographical coordinates were recorded in the system WGS 84, Garmin eTrex Vista device was used.

Sampling sites:

1) Sub-Tatra Furrow, Tiborova pol'ana, $933 \mathrm{~m}$ a.s.l., coordinates 49¹7'44.06"; 2009'21.94", October 25, 2012.

2) Big Fatra Mts, Turčianska Štiavnička settlement, $532 \mathrm{~m}$ a.s.l., coordinates $49^{\circ} 04^{\prime} 27.66^{\prime \prime} ; 19^{\circ} 01^{\prime} 15.24 "$ November 1, 2012.

3) High Tatra Mts, Jakubkova lúka, 1080 m a.s.l., coordinates 4908'28"; 20¹2'44", November 4, 2012.

4) High Tatra Mts, Javorová dolina valley, $1050 \mathrm{~m}$ a.s.1., coordinates $49^{\circ} 15^{\prime} 26.82^{\prime \prime} ; 20^{\circ} 08^{\prime} 47.64^{\prime \prime}$, October 16, 2012.

5) Small Fatra Lučanská, under Martinské hole hills, $575 \mathrm{~m}$ a.s.l., coordinates $49^{\circ} 06^{\prime} 02.12^{\prime \prime} ; 18^{\circ} 52^{\prime} 37.98^{\prime \prime}$ October 25, 2012.

6) Sub-Tatra Furrow, Nature Reserve Bor, 957 m a.s.l., coordinates 49 $16^{\prime} 34.5^{\prime \prime} ; 20^{\circ} 09^{\prime} 40.6^{\prime \prime}$, October 25, 2012.

7) Sub-Tatra Furrow, Nature Reserve Bor, 950 m a.s.l., coordinates 49¹6'43.02"; 2009'57.00", October 25, 2012.

\subsection{Instrumental Analysis}

The tissue samples were analyzed by X-ray fluorescence [18], using the hand-held XRF spectrometer DELTA CLASSIC (USA). The following elements were determined: $\mathrm{S}, \mathrm{Pb}, \mathrm{K}, \mathrm{Ca}, \mathrm{Cr}, \mathrm{Mn}, \mathrm{Fe}, \mathrm{Cu}, \mathrm{Rb}, \mathrm{Sr}, \mathrm{Mo}, \mathrm{Ba}, \mathrm{Zn}$. Since some examined elements need different thickness of pellets, e. g. S versus $\mathrm{Pb}$ [19] we have decided to use method without pelletization [20-22]. The plant material was crushed in mortar into fine powder. The epoxide frame of $2.0 \times 2.4 \mathrm{~cm}$ was filled with $1-1.2 \mathrm{~g}$ of plant powder, up to $1 \mathrm{~cm}$ in thickness and analysed directly on protective prolen folium. The accuracy of XRF method is proportional to the mass, to the concentration of elements and to the analysing time. Experimentaly we found the optimal analysing time for $30 \mathrm{sec}$. We have decided for three repetitions. Samples dried at $60^{\circ} \mathrm{C}$ for 24 hours. Analysis using XRF allows analyze the compact samples without homogenisation. The whole surface of samples was exposed to radiation, the angle of the beam was $90^{\circ}$. The measurement consists of seven replicates.

The samples placed in plastic sleeves are stored in the Institute of High Mountain Biology in Tatranská Javorina, Slovakia.

\subsection{Statistics}

For statistical analysis, the CANOCO 4.5 for Windows package [23] was used. To analyse the relation of environmental variables (element concentrations) and analysed moss segments we had only single data set of variable. Since the length of the first gradient in the log report was $<0.6$, we used the linear method of ordination (principal component analysis, the PCA). For ordination analysis we used ordinal elements concentration data without transformation. Statistical graphics system STATISTICA, Release 7 has been used for the correlation analysis and for analysis of variance.

Except for individual differentiation, the samples were sorted into groups according to location (Tatra Mts-Fatra Mts), according to age (One year-More year segments) and according to generation (Gametophyte-Sporophyte). The differences between ecological groups were tested with one-way analysis of variance (ANOVA) of the component scores.

Population of Polytrichum commune growing in swampy spruce forest in locality Tiborová (Sub-Tatra Furrow) have been found richly fruitful, the moss is growing in large carpets, herbaceous cover is insignificant. A negative effect of the herbaceous cover and its species rich- 
ness on the abundance of P. commune was observed [24], we are entitled to assume the optimal ecological conditions in the locality Tiborová. In order to identify the associations among set of variables relating to the population of Polytrichum commune growing in optimal condition and other sets of variables we used canonical correlations.

\section{Results and Discussion}

The first axis explains $77.9 \%$ of variance, this axis positively correlates with elements concentrating in capsula, i.e. zinc, chromium, manganese, copper, calcium, molybdenum and negatively correlates with lead, which has an affinity to gametophyte. The second axis explains $21.7 \%$ of variance, this axis positively correlates with elements concentrating in seta, i.e. rubidium and in a lesser extent with potassium and stroncium.

Lead occurs preferably in gametophyte, both in leaves and stems ( $p=0.057$, Figure 1, Tables 1 and 2), particularly in the more year segments $(p=0.187)$. The oc- curence in the leaves prefers baryum $(p=0.197)$. Potassium favors sporophyte $(p=0.181$, Figure 1, Tables 1 and 2), occuring in seta, also in the capsula. While potassium occuring in the gametophyte, prefers one-year segments $(p=0.186$, Table 2$)$. Strontium slightly favors sporofyte also ( $p=0.290$, Figure 1, Tables 1 and 2), but while ocuring in gametophyte, gives priority to moreyear segments $(p=0.125$, Figure 1, Tables 1 and 2). Molybdenum slightly favors sporophyte $(p=0.216$, Figure 1, Tables 1 and 2). A high concentration of some metals in capsula exhibit zinc, chromium, manganese, copper, of the non-metals sulphur (Figure 1), but zinc is significantly concentrated in stems $(p=0.048)$. Iron slightly prefers gametophyte $(p=0.313)$, significantly occurs in more year segments $(p=0.037$, Figure 1, Tables 1 and 2). Rubidium prefers accumulation in seta, but insignificantly.

Copper and chromium predominate in The Fatra Mts significantly $(\mathrm{Cu} \mathrm{p}=0.035 ; \mathrm{Cr} \mathrm{p}=0.020)$, close to significancy predominate in The Fatra Mts sulphur ( $p=$

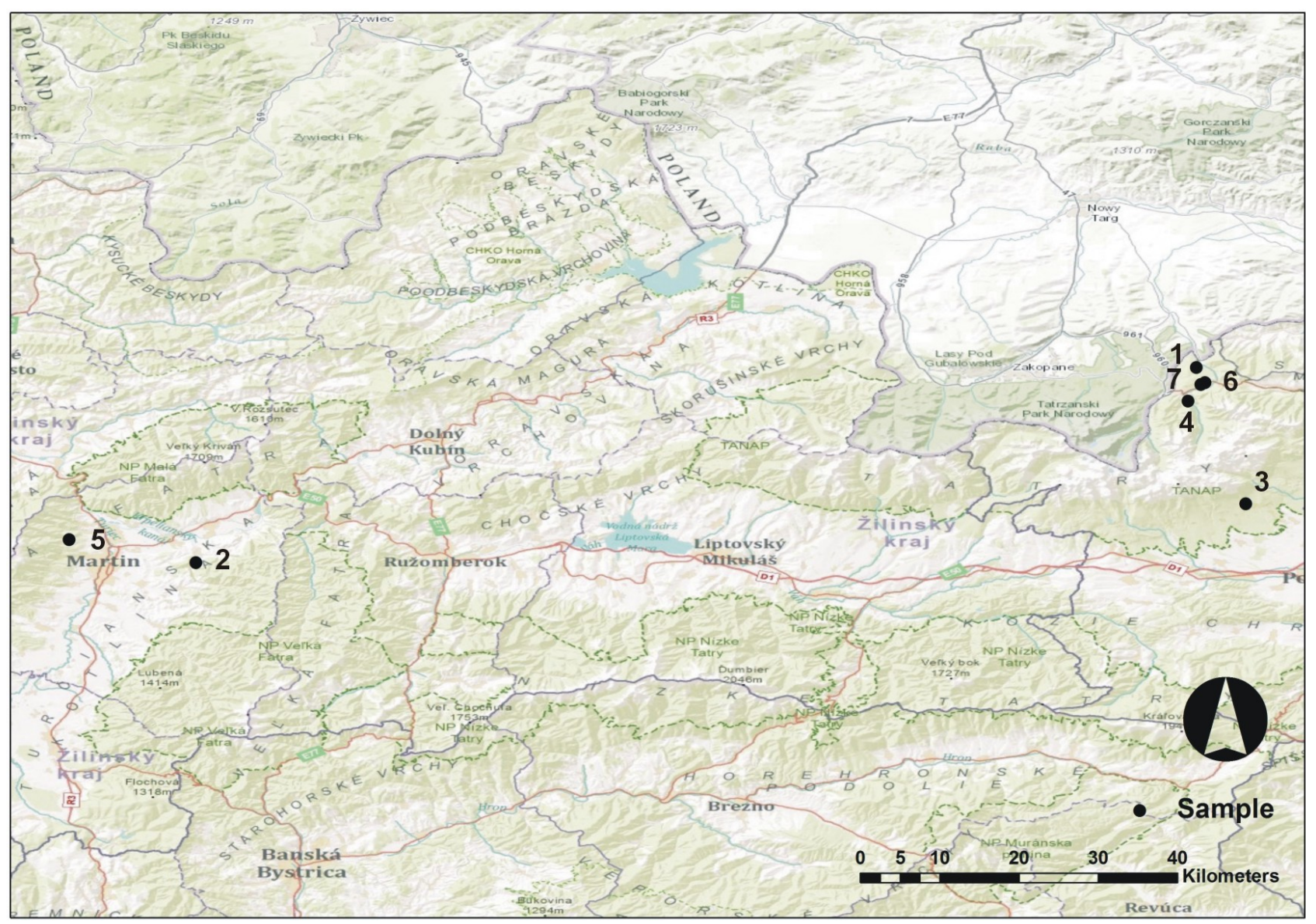

Figure 1. Map of sampling sites: 1: Sub-tatra furrow, Tiborova pol’ana; 2: Big Fatra Mts, Turčianska Štiavnička settlement; 3: High Tatra Mts, Jakubkova lúka meadow; 4: High tatra Mts, Javorová dolina valley; 5: Small Fatra Lučanská, under Martinské hole hills; 6: Sub-tatra furrow, nature reserve Bor; 7: Sub-tatra furrow, nature reserve Bor. (Drawn by J. Solár). 
Based on XRF Spectrometry

Table 1. Heavy metals and sulphur concentrations (ppm) in growth segments of Polytrichum commune.

\begin{tabular}{|c|c|c|c|c|c|c|c|c|c|c|c|c|c|}
\hline & $\mathrm{S}$ & $\mathrm{K}$ & $\mathrm{Ca}$ & $\mathrm{Cr}$ & $\mathrm{Mn}$ & $\mathrm{Fe}$ & $\mathrm{Cu}$ & $\mathrm{Zn}$ & $\mathrm{Rb}$ & $\mathrm{Sr}$ & Mo & $\mathrm{Ba}$ & $\mathrm{Pb}$ \\
\hline \multicolumn{14}{|c|}{ Site 1} \\
\hline Capsules & 4306 & 42,336 & 20,179 & 109 & 1339 & 982 & 58 & 532 & 58 & 8.7 & 15 & 115 & 23 \\
\hline Seta & nd & 42,840 & 8238 & 37 & 925 & 197 & 30 & 132 & 76 & 9.9 & 10.3 & 53 & 21 \\
\hline One-year leaves & 3154 & 13,592 & 5225 & 72 & 484 & 1893 & 34 & nd & 27 & ND & 10 & 113 & 44 \\
\hline More-year leaves & 4038 & 14,061 & 9265 & 106 & 794 & 3277 & 33 & nd & 29 & ND & 13 & 171 & 38 \\
\hline One-year stems & 2269 & 11,315 & 3905 & 39 & 392 & 466 & 24 & 65 & 35 & 3.3 & 7.9 & 55 & 27 \\
\hline More-year stems & 1925 & 5822 & 2698 & 26 & 278 & 456 & nd & 19 & 32 & 2.3 & 6.1 & 54 & 33 \\
\hline \multicolumn{14}{|c|}{ Site 2} \\
\hline Capsules & 13,378 & 41,094 & 116,174 & 474 & 1640 & 3467 & 87 & nd & 30 & 11 & 19 & 200 & nd \\
\hline Seta & 4404 & 51,643 & 23,898 & 126 & 627 & 1340 & nd & nd & 28 & 6.4 & 18 & 166 & 26 \\
\hline One-year leaves & 5973 & 23,501 & 21,493 & 79 & 390 & 2628 & 50 & nd & 26 & 6.2 & 9 & 183 & 36 \\
\hline More-year leaves & 3932 & 17,464 & 20,280 & 72 & 322 & 3259 & 46 & nd & 28 & 10.5 & 12 & 170 & 39 \\
\hline One-year stems & 4417 & 25,637 & 14,588 & 72 & 303 & 1601 & 47 & nd & 32 & 8 & 12 & 125 & 29 \\
\hline More-year stems & 3224 & 12,516 & 10,858 & 33 & 206 & 2763 & 22 & 39 & 30 & 12.8 & 10.1 & 108 & 30 \\
\hline \multicolumn{14}{|c|}{ Site 3} \\
\hline Capsules & 5135 & 19,661 & 26,758 & 147 & 2760 & 1948 & 38 & 229 & 42 & 22 & 16 & 150 & 33 \\
\hline Seta & 1906 & 7197 & 9567 & 40 & 1409 & 507 & 23 & 152 & 28 & 26.4 & 8.7 & 76 & 29 \\
\hline One-year leaves & 2014 & 8955 & 6989 & 63 & 875 & 1703 & 32 & 23 & 27 & 11.4 & 12 & 113 & 31 \\
\hline More-year leaves & 3223 & 12,519 & 15,593 & 166 & 1771 & 2516 & nd & nd & 22 & 10 & 14 & 231 & 33 \\
\hline One-year stems & 2075 & 8055 & 4864 & 31 & 728 & 647 & 16 & 89 & 27.6 & 15.5 & 9.4 & 67 & 25 \\
\hline More-year stems & 1220 & 8674 & 3032 & 21 & 416 & 320 & ND & 37 & 30.1 & 12.2 & 9.1 & 32 & 22 \\
\hline \multicolumn{14}{|c|}{ Site 4} \\
\hline Capsules & 7326 & 23,628 & 50,812 & 95 & 1417 & 803 & 50 & 87 & 31 & 11.2 & 9 & 116 & 19 \\
\hline Seta & nd & 51,566 & 16,805 & 77 & 726 & 553 & 31 & nd & 45 & 8.1 & 13 & 112 & 33 \\
\hline One-year leaves & 4962 & 23,839 & 15,901 & 94 & 643 & 1639 & 37 & nd & 33 & 5.1 & 12 & 170 & 36 \\
\hline More-year leaves & 5415 & 17,451 & 21,026 & 84 & 947 & 3155 & 52 & nd & 32 & 12.1 & 13 & 206 & 53 \\
\hline One-year stems & 2521 & 13,822 & 8405 & 42 & 402 & 806 & 43 & 62 & 31 & 5.3 & 9.1 & 86 & 28 \\
\hline More-year stems & 3066 & 12,865 & 9019 & 37 & 371 & 1047 & 21 & 21 & 35 & 8.5 & 8.9 & 92 & 37 \\
\hline \multicolumn{14}{|c|}{ Site 5} \\
\hline Capsules & 9077 & 38,571 & 39,711 & 153 & 3526 & 1509 & 78 & nd & 30 & 23 & 17 & 222 & 18 \\
\hline Seta & nd & 36,916 & 16,448 & 83 & 1934 & 2671 & nd & nd & 42 & 28 & 10 & 187 & 19 \\
\hline One-year leaves & 4206 & 23,843 & 11,054 & 71 & 1291 & 4336 & 33 & nd & 38 & 22 & 8 & 198 & 31 \\
\hline More-year leaves & 3872 & 21,152 & 16,798 & 98 & 2529 & 9880 & 38 & nd & 51 & 37 & 9 & 309 & 35 \\
\hline One-year stems & 4557 & 20,792 & 8144 & 47 & 1072 & 1561 & 32 & nd & 43 & 21.8 & 10.3 & 142 & 30 \\
\hline More-year stems & 3288 & 22,243 & 9570 & 49 & 965 & 5184 & 17 & nd & 50 & 36 & 10.3 & 182 & 31 \\
\hline \multicolumn{14}{|c|}{ Site 6} \\
\hline Capsules & nd & 33,599 & 29,084 & 99 & 1989 & 578 & 39 & 435 & 51 & 6.5 & 11 & 78 & 21 \\
\hline Seta & nd & 42,504 & 7188 & 37 & 1492 & 210 & 16 & 52 & 70 & 9.1 & 8.7 & 51 & 26 \\
\hline One-year leaves & 3692 & 35,768 & 6360 & 81 & 970 & 888 & 29 & nd & 35 & nd & 9 & 109 & 23 \\
\hline More-year leaves & 3816 & 22,545 & 9014 & 93 & 1154 & 1082 & 33 & nd & 30 & nd & 10 & 171 & 22 \\
\hline One-year stems & 1731 & 20,845 & 3911 & 27 & 758 & 163 & 23 & 64 & 42 & 3.1 & 8.6 & 39 & 23 \\
\hline More-year stems & 1190 & 12,238 & 2069 & 17 & 436 & 160 & 14 & 35 & 39.6 & 1.8 & 7.6 & 32 & 17 \\
\hline \multicolumn{14}{|c|}{ Site 7} \\
\hline Capsules & 4945 & 16,348 & 15,028 & 10 & 1284 & 1130 & nd & 538 & 29 & 1 & nd & 21 & 10 \\
\hline Seta & nd & 36,793 & 6339 & 11 & 831 & 686 & 15 & 146 & 83 & 9.2 & 5.9 & 20 & 15 \\
\hline One-year leaves & 3004 & 13,972 & 2967 & 6 & 283 & 606 & nd & 36 & 18 & nd & nd & 20 & 10 \\
\hline More-year leaves & 2660 & 8089 & 4976 & 20 & 540 & 1597 & nd & 41 & 13 & nd & nd & 75 & 17 \\
\hline One-year stems & 1902 & 10,746 & 2220 & nd & 218 & 277 & nd & 73 & 16.6 & 1.6 & nd & nd & 6 \\
\hline More-year stems & 1732 & 9605 & 1714 & nd & 149 & 362 & nd & 47 & 20.5 & 1.7 & 3.1 & nd & 10 \\
\hline
\end{tabular}

nd: below detection limit. 
Table 2. Results of ANOVA, distribution of elements with respect to generations (gametophyte-sporophyte), segments age (one year-more year) and The West Carpathians mountain ranges (Tatra Mts, including).

\begin{tabular}{ccccccc}
\hline & \multicolumn{2}{c}{ Gametophyte-sporophyte } & \multicolumn{2}{c}{ One year-more year segments } & \multicolumn{2}{c}{ Tatra Mts-Fatra Mts } \\
\hline & $\mathrm{F}$ & $\mathrm{P}$ & $\mathrm{F}$ & $\mathrm{p}$ & $\mathrm{F}$ & $\mathrm{p}$ \\
\hline $\mathrm{Pb}$ & 175.5 & 0.057 & 15.62 & 0.187 & 1.512 & 0.547 \\
$\mathrm{~S}$ & 6.780 & 0.280 & 0.379 & 0.820 & 170.2 & 0.058 \\
$\mathrm{~K}$ & 16.79 & 0.181 & 13.20 & 0.186 & 2.966 & 0.413 \\
$\mathrm{Ca}$ & 0.948 & 0.683 & 0.134 & 0.948 & 3.813 & 0.370 \\
$\mathrm{Cr}$ & 2.694 & 0.425 & 0.948 & 0.637 & 1432.2 & 0.020 \\
$\mathrm{Mn}$ & 27.70 & 0.142 & 10.54 & 0.227 & 2.417 & 0.445 \\
$\mathrm{Fe}$ & 5.310 & 0.313 & 368.1 & 0.037 & 6.836 & 0.282 \\
$\mathrm{Cu}$ & 4.538 & 0.337 & 0.99 & 0.627 & 387.8 & 0.035 \\
$\mathrm{Rb}$ & 1.294 & 0.571 & 12.46 & 0.209 & 82.74 & 0.083 \\
$\mathrm{Sr}$ & 7.029 & 0.290 & 31.25 & 0.125 & 10.57 & 0.226 \\
$\mathrm{Mo}$ & 10.55 & 0.226 & 0.08 & 0.975 & 49.40 & 0.108 \\
$\mathrm{Ba}$ & 1.659 & 0.519 & 7.61 & 0.265 & 2.957 & 0.414 \\
$\mathrm{Zn}$ & 29.55 & 0.137 & 0.90 & 0.648 & 1.614 & 0.534 \\
\hline
\end{tabular}

0.058), insignificantly predominates in The Fatra Mts rubidium ( $p=0.083$ ) (Table 2). Except for the effects of the Silesian and Polish metalurgy, an important source of polymetallic deposition impacting The Fatra Mts is domestic Ferrous-Alloy Mills Istebné. The key components are $\mathrm{Mn}, \mathrm{Cr}$ the other risk elements are $\mathrm{Ti}, \mathrm{Zr}, \mathrm{Cu}, \mathrm{Pb}$ [25]. With a regard to the distribution of chromium and copper (Tatra Mts-Fatra Mts, Table 2), our results confirmed this conclusions [25].

Differences in heavy metals accumulation in both gametophyte and sporophyte have been recorded by more authors. Xie and Zhang [12] noticed that gametophytes of Funaria hygrometrica accumulated significantly more heavy metals than sporophytes, while concentrations of $\mathrm{Zn}$ and $\mathrm{Mn}$ in sporophytes were always higher than concentrations of other heavy metals. Similar results noticed Basile et al. [13], also using Funaria hygrometica.

We have recorded higher concentrations of $\mathrm{Zn}$ and $\mathrm{Mn}$ in the sporophyte of Polytrichum commune also (Tables 1 and 2, Figure 1). Brown and Buck [26] found, that degeneration of the gametophyte of Funaria hygrometrica was accompanied by loss of $\mathrm{K}$ and a gain in $\mathrm{Ca}$.

Every set of variables highly correlates with the set of independent variables, except for location $\mathrm{Nr}$. 3, nevertheless, the correlation is close to significancy $(\mathrm{p}=0.057$, Table 3). From the ecological point of view, site 3 is a slightly different location. This is the highest localized sampling site (1080 $\mathrm{m}$ a.s.1.) placed in the south facing slope of The High Tatra Mts. The others are located on the northern slopes of the The Tatra Mountains, or have their origin in The Fatra Mts.

Vázquez et al. [27] found that metals are mostly taken up to the extracellular compartment than to the intracellular compartment, nevertheless zinc prefers intracellular compartment [28]. Polytrichales have highly developed conducting strands [29]. An internal water-conducting system consists of highly elongate cells lacking cytoplasmic contents at maturity. Traditionaly these cells are colled hydroids and form a central strand which is sometimes referred to as hydrom [29] and outer leptom. Hydroides are specialized for conduction of water. Leptom of Polytrichum stem conduct assimilates and ionic solutes such as sulphate and lead [30]. High enzymatic activity is indirect evidence for the role of leptoides in conduction of organic compounds [30], ions are accumulated in the leptom cells [31]. The accumulated elements are during vegetation period transfered to their growing tips. We have found, that most rapidly is increasing $\mathrm{K}$ and $\mathrm{Ca}$ content of developing sporophyte, this was observed by Brown and Buck [26] also.

It seems that some bryophytes thrives in polluted environments. Species commonly growing in such environments, like Pohlia nutans, produce protonemata and gametophytes much faster [32]. Bryum argenteum frequently occurs in urban environments and therefore appears to have the ability to tolerate high levels of such atmospheric pollutants as lead. Plants from different populations contained extremely different concentrations of lead and other metals. Panda and Choudhury [33] investigated the effect of chromium, copper and zinc on nitrate reductase activity and on total chlorophyll content in the moss Polytrichum commune. The response of Polytrichum commune to toxic concentrations of $\mathrm{Cr}, \mathrm{Cu}$ and $\mathrm{Zn}$ appears to induce oxidative damage as observed by increase in malondialdehyde content.

Klavina et al. [34] recorded following concentration in Polytrichum commune (ppm) K 6210, Ca 2561, Fe 779,

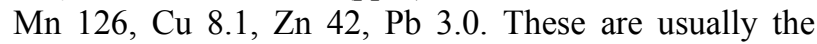


Table 3. Canonical correlation, sums of partial elements concentrations (ppm) in growth segments.

\begin{tabular}{|c|c|c|c|c|c|c|c|c|c|}
\hline & Capsule & Seta & One y-leaves & More-y-leaves & One-y-stems & More-y-stems & Eigen values & Canonical correlation & $\mathrm{p}$ \\
\hline \multicolumn{10}{|c|}{ Independent variables } \\
\hline 1 & 70,061 & 52,569 & 24,648 & 31,825 & 18,603 & 11,351 & & & \\
\hline \multicolumn{10}{|c|}{ Dependent variables } \\
\hline 2 & 176,574 & 82,282 & 54,374 & 45,635 & 46,871 & 29,852 & 0.8498 & 0.9219 & 0.0100 \\
\hline 3 & 56,939 & 20,969 & 20,848 & 36,098 & 16,649 & 13,826 & 0.6447 & 0.8029 & 0.0570 \\
\hline 4 & 84,404 & 69,969 & 47,371 & 48,446 & 26,262 & 26,628 & 0.9560 & 0.9778 & 0.0009 \\
\hline 5 & 92,935 & 58,338 & 45,131 & 54,808 & 36,452 & 41,625 & 0.8674 & 0.9313 & 0.0072 \\
\hline 6 & 65,990 & 51,664 & 44,272 & 34,154 & 25,907 & 15,067 & 0.8737 & 0.9347 & 0.0071 \\
\hline 7 & 39,344 & 44,954 & 20,922 & 18,028 & 15,460 & 13,644 & 0.8180 & 0.9044 & 0.0146 \\
\hline
\end{tabular}

concentrations that correspond with our measured values, except for $\mathrm{Mn}, \mathrm{Zn}$ and $\mathrm{Pb}$, where our values are higher. Busuioc et al. [7] recorded extreme high chromium concentration in Polytrichum commune, of 2040 ppm.

Polytrichum commune sensitively responds to the nutrient supply. When ecological conditions are changed, the moss quickly occupy appropriate habitats [35]. At the sub-arctic Abisco site the mosses showed individualistic response to environmental changes (temperature, nutriaents). While Hylocomium splendes showed reduced growth due to increased temperature or increased nutrient supply, Polytrichum commune increased its growth when nutriaents were added [36].

\section{Conclusions}

- Zinc, chromium, manganese, molybdenum, kalcium, copper and of the non-metals sulphur are preferentially accumulated in the capsula.

- If Polytrichum commune is used as bioidicator, the structure of samples collected must be unified in the whole monitored territory (only gametophyte or only gametophyte + sporophyte), because some elements are particularly accumulated in sporophytes.

- Lead prefers accumulation in gametophyte, potassium, strontium slightly prefers accumulation in sporophyte.

- While zinc accumulates in the stems, iron significantly accumulates in the more-year segments.

- Increased accumulation of copper, chromium and sulphur in The Fatra Mts indicate increased immision deposition in this area.

\section{Acknowledgements}

The authors thank the Norwegian Financial Mechanisms of the research project SK 1551/2012. The authors are indebted to Tomas Hallingbäck, the Swedish Species Information Centre, for reading the text and for constructive suggestions.

\section{REFERENCES}

[1] G. Tyler, "Bryophytes and Heavy Metals, a Literature Review," Botanical Journal of the Linnean Society, Vol. 104, No. 1-3, 1990, pp. 231-253. doi:10.1111/j.1095-8339.1990.tb02220.x

[2] M. Sabovljević, V. Vukojević, N. Mihajlović, G. Dražić and Z. Vučinić, "Determination of Heavy Metal Deposition in the County of Obrenovac (Serbia) Using Mosses as Bioindicators, I: Aluminum (Al), Arsenic (As), and Boron (B)," Archives of Biological Sciences, Vol. 57, No. 3, 2005, pp. 205-212. doi:10.2298/ABS0503205S

[3] R. Šltés, "Heavy Metal Concentrations in the Mosses of the Tatra Mountains (Czecho-Slovakia): Multivariate Analysis," Oecologia Montana, Vol. 1, No. 1, 1992, pp. 3136.

[4] R. Šoltés, "Correlation between Altitude and Heavy Metal Deposition in the Tatra Mts (Slovakia)," Biologia, Vol. 53, No. 1, 1998, pp. 85-90.

[5] S. S. Sidhu, "Fluoride Levels in Air, Vegetation and Soil in the Vicinity of a Phosphorus Plant," Journal of the Air Pollution Control Association, Vol. 29, No. 10, 1979, pp. 1069-1072. doi:10.1080/00022470.1979.10470899

[6] L. H. Wenstein and A. W. Davison, "Native Plant Species Suitable as Bioindicators and Biomonitors for Airborne Fluoride," Environmental Pollution, Vol. 125, No. 1, 2003, pp. 3-11. doi:10.1016/S0269-7491(03)00090-3

[7] G. Busuoic, I. David, M. Sencovici and N. Iliescu, "Evaluation of Capacity for Bioaccumalation of Some Heavy Metals in Three Aquatic Plants Species," In: P. Gâştescu, W. Lewis Jr. and P. Brețcan, Eds., Proceedings of the Water Resources and Wetlands, Tulcea, 14-16 September 2012, pp. 220-223.

[8] V. Irudayaraj, M. Johnson, A. S. Priyakumari and P. A. Janani, "Effect of Heavy Metal Stress on Spore Germination of Pteris confusa T. G. Walker and Pteris argyraea T. Moore," Journal of Stress Physiology \& Biochemistry, Vol. 7, No. 4, 2011, pp. 1208-216.

[9] B. Markert and W. Wtorova, "Inorganic Chemical Investigations in the Forest Biosphere Reserve near Kalinin, USSR,” Vegetatio, Vol. 98, No. 1, 1992, pp. 43-58. doi:10.1007/BF00031636

[10] R. Šoltés, A. Šoltésová and Z. Kyselová, "Vplyv Imisií na 
Nelesnú Vegetáciu Vysokých a Belianskych Tatier," Zborník prác o Tatranskom Národnom Parku, No. 32, 1992, pp. 307-333.

[11] B. Maňkovská, M. Florek, M. V. Frontasyeva, E. Ermakova, K. Oprea and S. S. Pavlov, "Atmospheric Deposition of Heavy Metals in Slovakia Studied by the Moss Biomonitoring Technique, Neutron Activation and Lame Atomic Absorption Spectrometry," Ecologia, Vol. 22, No. 1, 2003, pp. 157-162.

[12] F. Xie and Z. H. Zhang, "Accumulation Characteristic of Heavy Metals between Gametophytes and Sporophytes of Moss Funaria hygrometrica," Bulletin of Botanical Research, Vol. 31, No. 1, 2011, pp. 117-120.

[13] A. Basile, A. E. Cogoni, P. Bassi, E. Fabrizi, S. Sorbo, S. Giordano and R. C. Cobianchi, "Accumulation of $\mathrm{Pb}$ and $\mathrm{Zn}$ in Gametophytes and Sporophytes of the Moss Funaria hygrometrica (Funariales)," Annals of Botany, Vol. 87, No. 4, 2001, pp. 537-543.

[14] E. J. Bowen, "Water Conduction in Polytrichum commune," Annals of Botany, Vol. 45, No 1, 1931, pp. 175200.

[15] N. Ljubešić, M. Wrischer, T. Prebeg and Z. Devidé, "Structural Changes of Lamellar Cells in Leaves of the Moss Polytrichum formosum Hedw. during Winter Freezing and Thawing Processes," Acta Botanica Croatica, Vol. 64, No. 2, 2005, pp. 219-226.

[16] K. Grodzińska and B. Godzik, "Heavy Metals and Sulphur in Mosses from Southern Spitzbergen," Polar Research, Vol. 9, No. 2, 1991, pp. 133-140. doi:10.1111/j.1751-8369.1991.tb00609.x

[17] M. A. Watson, "Annual Periodicity of Incremental Growth in the Moss Polytrichum commune," The Bryologist, Vol. 78, No. 4, 1975, pp. 414-422. doi:10.2307/3242163

[18] W. E. Stephens and A. Calder, "Analysis of Non-Organic Elements in Plant Foliage Using Polarised X-Ray Fluorescence Spektrometry," Analytica Chimica Acta, Vol. 527, No. 1, 2004, pp. 89-96.

[19] D. H. S. Richardson, M. Shoreb, R. Hartreeb and R. M. Richardson, "The Use of X-Ray Fluorescence Spectrometry for the Analysis of Plants, Especially Lichens, Employed in Biological Monitoring," Science of the Total Environment, Vol. 176, No. 1-3, 1995, pp. 97-105.

[20] M. Stikans, J. Boman and E. S. Lindgren, "Improved Technique for Quantitative XRF Analysis of Powdered Plant Samples," X-Ray Spectrometry, Vol. 27, No. 6, 1988, pp. 367-372.

[21] J. Boman, H. Blanck, P. Standzenieks, R. P. Pettersson and N. T. Hong, "Sample Preparation and EDXRF Analysis of Element Content in Marine Algal CommunitiesA Tentative Approach," X-Ray Spectrometry, Vol. 22, No. 4, 1993, pp. 260-264. doi:10.1002/xrs.1300220416

[22] A. Aslan, G. Budak and A. Karabulut, "The Amount Fe, $\mathrm{Ba}, \mathrm{Sr}, \mathrm{K}, \mathrm{Ca}$, and $\mathrm{Ti}$ in Some Lichens Growing in Erzurum Province (Turkey)," Journal of Quantitative Spectroscopy and Radiative Transfer, Vol. 88, No. 4, 2004, pp. 423-431.

[23] C. J. F. Ter Braak and P. Šmilauer, "CANOCO Reference Manual and CanoDraw for Windows User's Guide. Soft- ware for Canonical Community Ordination (Version 4.5)," Biometris, Wageningen \& České Budějovice, 2002.

[24] P. Sugier and B. Czarnecka, "Vascular Plants versus Mosses in Lakeland and Riverine Mires in Two Regions of Eastern Poland," Polish Journal of Ecology, Vol. 58, No. 4, 2010, pp. 635-644.

[25] A. Fargašová, “Znečistenie Kovmi na Slovensku,” 2009. http://www.enviro-edu.sk/?page=environmentalne_proble my/znecistenie_kovmi_na_slovensku

[26] D. H. Brown and G. W. Buck, "Distribution of Potassium, Calcium and Magnesium in the Gametophyte and Sporophyte Generations of Funaria hygrometrica Hedw.," Annals of Botany, Vol. 42, No. 4, 1978, pp. 923-929.

[27] M. D. Vázquez, J. López and A. Carballeira, "Uptake of Heavy Metals to the Extracellular and Intracellular Compartments in Three Species of Aquatic Bryophyte," Ecotoxicology and Environmental Safety, Vol. 44, No. 1, 1999, pp. 12-24. doi:10.1006/eesa.1999.1798

[28] M. Sidhu and D. H. Brown, "A New Laboratory Technique for Studying the Effects of Heavy Metals on Bryophyte Growth," Annals of Botany, Vol. 78, No. 6, 1996, pp. 711-717. doi:10.1006/anbo.1996.0181

[29] R. Ligrone, J. G. Duckett and K. S. Renzaglia, "Conducting Tissues and Phyletic Relationships of Bryophytes," Philosophical Transactions of the Royal Society of London, Vol. 355, No. 1398, 2000, pp. 795-813.

[30] R. N. Chopra and P. K. Kumra, "Biology of Bryophytes," New Age International Pvt Ltd Publishers, 2005.

[31] S. Trachtenberg and E. Zamski, "Conduction of Ionic Solutes and Assimilates in the Leptom of Polytrichum juniperinum Willd.," Journal of Experimental Botany, Vol. 29, No. 3, 1978, pp. 719-727. doi:10.1093/jxb/29.3.719

[32] S. Huttunen, "Reproduction of the Mosses Pleurozium schreberi and Pohlia nutans in the Surroundings of Copper Smelters at Harjavalta, SW Finland," Journal of Bryology, Vol. 25, No. 1, 2003, pp. 41-47. doi: $10.1179 / 037366803125002644$

[33] S. K. Panda and S. Choudhury, "Changes in Nitrate Reductase Activity and Oxidative Stress Response in the Moss Polytrichum commune Subjected to Chromium, Copper and Zinc Phytotoxicity," Brazilian Journal of Plant Physiology, Vol. 17, No. 2, 2005, pp. 191-197. doi:10.1590/S1677-04202005000200001

[34] L. Klavina, O. Bikovens, I. Šteinberga, V. Maksimova and L. Eglite, "Characterization of Chemical Composition of Some Bryophytes Common in Latvia," Environmental and Experimental Biology, No. 10, 2012, pp. 27-34.

[35] A. Odland and R. Moral, "Thirteen Years of Wetland Vegetation Succession Following a Permanent Drawdown, Myrkdalen Lake, Norway," Plant Ecology, Vol. 162, No. 2, 2002, pp. 185-198. doi:10.1023/A:1020388910724

[36] T. V. Callaghan, M. C. Press, J. A. Lee, D. L. Robinson and C. W. Anderson, "Spatial and Temporal Variability in the Responses of Arctic Terrestrial Ecosystems to Environmental Change, " Polar Research, Vol. 18, No. 2, 1999, pp. 191-197. doi:10.1111/j.1751-8369.1999.tb00293.x 